\title{
IDENTIFIKASI RISIKO POSTUR KERJA PADA PERIKANAN PURSE SEINE
}

\author{
Risk Identification of Work Postures in Purse Seine Fishery \\ Oleh: \\ Muhammad Iqbal ${ }^{1 *}$, Fis Purwangka ${ }^{1}$, Budy Wiryawan ${ }^{1}$ \\ ${ }^{1}$ Program Studi Teknologi dan Manajemen Perikanan Tangkap \\ "Korespondensi: iqba1972010@gmail.com
}

\begin{abstract}
ABSTRAK
Kegiatan penangkapan ikan melibatkan kapal perikanan, alat tangkap dan nelayan. Aktivitas penangkapan ikan dengan kapal purse seine di Rembang dilakukan secara manual sehingga dapat menyebabkan gangguan musculoskeletal. Tujuan penelitian ini yaitu mengidentifikasi kondisi postur kerja nelayan saat melakukan penangkapan ikan dengan alat tangkap purse seine, mengidentifikasi kondisi yang tergolong membahayakan bagi otot dan gangguan musculoskeletal yang dirasakan setelah melakukan aktivitas penangkapan. Data yang digunakan berupa sikap tubuh saat melakukan aktivitas penangkapan ikan yang diperoleh melalui observasi lapang. Data keluhan otot yang dirasakan setelah melakukan aktivitas penangkapan ikan diperoleh dari wawancara terhadap nelayan purse seine sebanyak 100 responden. Data sikap tubuh diolah menggunakan metode Ovako Working Posture Analysis System (OWAS) merupakan metode untuk menganalisa postur kerja yang dapat menyebabkan keluhan otot, meliputi pergerakan tubuh bagian punggung, bahu, tangan dan kaki, termasuk paha, lutut dan pergelangan kaki. Nordic body map merupakan metode untuk mengetahui keluhan otot yang dirasakan pada bagian tubuh. Hasil penilitian menunjukan bahwa aktivitas penangkapan ikan melibatkan sikap kerja berdiri yaitu pada aktivitas perbekalan, setting, hauling, pemasangan rumpon, bongkar muat dan sikap kerja duduk pada aktivitas sortir ikan dan perbaikan jaring. Aktivitas yang tergolong membahayakan adalah dengan mengangkat beban dalam kondisi ketika mengangkat beban melebihi bahu seperti aktivitas perbekalan dan bongkar muat. Bagian atas tubuh yang paling banyak merasakan sakit adalah lengan atas kanan dan kiri, bagian tengah adalah punggung dan bagian bawah adalah betis kiri dan kanan.
\end{abstract}

Kata kunci: Aktivitas penangkapan ikan, Nordic body map, OWAS, Postur kerja

\section{ABSTRACT}

Fishing activities involve fishing vessels, fishing gear and fishermen. Fishing operation using purse seine fishing gear in Rembang is done manually, thus can cause musculoskeletal disorders. This study aims to identify fishing-work posture conditions with purse seine fishing gear, identify conditions that are classified as harmful to muscles and musculoskeletal disorders felt after carrying out arrest activities. The data used in the form of body posture when fishing activities were obtained through field observation. Data muscle complaints that are felt after fishing activities were obtained from interviews with purse seine fishermen as many as 100 respondents. Data on body posture was processed using the Ovako Working Posture Analysis System (OWAS) method was a method to analyze work postures that can cause musculoskeletal disorders, including movement body parts of the back, shoulders, hands and feet, including thighs, knees and ankles. Nordic body map was a method to find out the muscle complaints felt on body parts. Results shows that fishing activities involve standing work attitudeson supply activities, settings, hauling, installation of FADs, loading and unloading, and sit work postures in the activity of sorting fish and repairing nets. Activities that were classified as dangerous was by lifting the load under conditions when lifting the load beyond the shoulder such as 
supplies and loading and unloading activities. Part of body that feel the pain more was the right and left upper arms, the middle part was the back and the part bottom was the left and right calf.

\section{Keywords: Fishing activity, Nordic body map, OWAS, Work posture}

\section{PENDAHULUAN}

Penangkapan ikan adalah kegiatan untuk memperoleh ikan di perairan yang tidak dalam keadaan dibudidayakan dengan alat atau cara apa pun, termasuk kegiatan yang menggunakan kapal untuk memuat, mengangkut, menyimpan, mendinginkan, menangani, mengolah, dan/atau mengawetkannya (UU No 45 2009). Kapal perikanan, alat tangkap ikan dan nelayan merupakan tiga faktor yang mendukung keberhasilan suatu operasi penangkapan ikan, terutama di laut merupakan kegiatan yang berisiko tinggi (Grainger 1993). Faktor keselamatan kapal maupun nelayan merupakan hal yang utama untuk menunjang kesuksesan suatu operasi penangkapan. Kapal perikanan adalah kapal, perahu, atau alat apung lain yang dipergunakan untuk melakukan penangkapan ikan, mendukung operasi penangkapan ikan, pembudidayaan ikan, pengangkutan ikan, pengolahan ikan, pelatihan perikanan, dan penelitian/eksplorasi perikanan (PERMEN KP No 71 2017). Menurut Nomura (1977) dalam Rhamadani (2004), kapal perikanan merupakan sarana untuk melakukan operasi penangkapan ikan yang digunakan untuk melakukan penangkapan ikan, dimana ukuran, kapasitas muat, rancangan bentuk dek, mesin serta berbagai perlengkapan yang secara keseluruhan disesuaikan fungsinya dalam rencana operasi penangkapan. Salah satu jenis kapal penangkap ikan adalah kapal purse seine. Kapal purse seine secara khusus dirancang untuk menangkap ikan layang, kembung, dan selar dengan alat tangkap jenis mini purse seine.

Kegiatan penangkapan ikan merupakan salah satu kegiatan yang paling membahayakan di dunia bagi para pelaut. Profesi sebagai pelaut/nahkoda/ABK kapal penangkapan ikan memiliki karakteristik pekerjaan "3D" yaitu: membahayakan (dangerous), kotor (dirty), dan sulit (difficult) (FAO 2000). Ketiga karakteristik tersebut ditambah faktor ukuran kapal terutama dengan menggunakan kapal purse seine cukuplah berisiko bila dilakukan dengan kondisi postur kerja yang tidak baik mengingat operasi penangkapan dilakukan di laut, karena keadaan di laut lepas tidak dapat diprediksi. Kegiatan penangkapan ikan juga sering menimbulkan kecelakaan kerja, maka dari itu perlu adanya penanganan yang baik terhadap postur kerja yang dilakukan ketika kegiatan operasi penangkapan ikan. Kegiatan di kapal purse seine dapat juga disebabkan oleh sikap, keterampilan dan pengetahuan nelayan yang rendah tentang keselamatan kerja di dek kapal (Purwangka 2013). Postur kerja merupakan titik penentu dalam menganalisa keefektifan dari suatu pekerjaan. Apabila postur kerja yang dilakukan oleh operator sudah baik dan ergonomis maka dapat dipastikan hasil yang diperoleh oleh operator tersebut akan baik. Akan tetapi bila postur kerja operator tersebut tidak ergonomis maka operator tersebut akan mudah kelelahan. Apabila operator mudah mengalami kelelahan maka hasil pekerjaan yang dilakukan operator tersebut juga akan mengalami penurunan dan tidak sesuai dengan yang diharapkan (Susihono 2012).

Musculoskeletal Disorder adalah masalah kesehatan yang melibatkan sendi, otot, tendon, kerangka, tulang rawan, ligamen, dan saraf (Van 2016). Tingkat musculoskeletal disorder dari yang paling ringan hingga yang berat akan menggangu konsentrasi dalam bekerja, menimbulkan kelelahan dan pada akhirnya akan menurunkan produktivitas (Harcombe 2014). Aktivitas kerja diatas kapal memiliki intensitas dan beratnya pekerjaan yang tinggi sehingga keluhan otot yang diakibatkan akan berdampak pada aktivitas penangkapan ikan dan dapat mengganggu kesehatan dan kenyamanan nelayan. Oleh sebab itu, diperlukan analisa dan pencatatan medis mengenai aktivitas yang dilakukan nelayan diatas kapal, sebagai data pendukung terhadap penyebab dan akibat yang dapat ditimbulkan oleh aktivitas penangkapan ikan purse seine. 


\section{METODE PENELITIAN}

Penelitian dan pengambilan data dilakukan pada bulan Februari 2018-Maret 2018 di Rembang. Penelitian ini dilakukan diperairan sejauh 75-120 mil dari PPP Tasikagung, Kecamatan Rembang Jawa Tengah. Pengambilan dan pengumpulan data primer dilakukan pada Februari sampai Maret 2018. Objek pengamatan dalam penelitian ini nelayan kapal purse seine di Pelabuhan Tasikagung Kabupaten Rembang Jawa Tengah.

Alat yang digunakan dalam penelitian adalah kamera, pensil, penghapus, kertas dan peralatan lain yang mendukung dalam pengumpulan data selama penelitian. Jenis data yang digunakan adalah data primer dan data sekunder. Pengambilan data primer dilakukan dengan observasi langsung dan wawancara dari kegiatan penangkapan ikan menggunakan alat tangkap purse seine. Pengambilan data sekunder didapatkan dari Dinas Perikanan Rembang yang digunakan untuk mengetahui jumlah kapal dan nelayan.

Analisis menggunakan metode OWAS (Ovako Working Posture Analysis System) untuk mengkelompokan sikap kerja pada bagian punggung, tangan, kaki dan berat beban serta dalam fase waktu tertentu dari kegiatan penangkapan ikan menggunakan purse seine. Masing-masing bagian memiliki klasifikasi sendiri-sendiri. Metode ini mengidentifikasi sikap kerja yang berpotensi menimbulkan kecelakaan kerja. Kecelakaan kerja yang menjadi perhatian dari metode ini adalah sistem musculoskeletal manusia. Postur dasar OWAS disusun dengan kode yang terdiri empat digit, disusun secara berurutan mulai dari punggung, lengan, kaki dan beban. Nelayan yang menjadi bahan pengamatan adalah nelayan purse seine di PPP Tasikagung. Selanjutnya dilakukan wawancara kepada nelayan terhadap keluhan otot yang dirasakan setelah melakukan aktivitas penangkapan ikan berjumlah 100 responden dengan menggunakapan kusioner Nordic Body Map diasumsikan kondisi kesehatan tubuh sama.

Penentuan jumlah sampel berdasarkan jumlah populasi nelayan purse seine yang dapat mewakili dari 14.818 nelayan yang ada di PPP Tasikagung. Jumlah 14.818 nelayan berdasarkan keseluruhan nelayan yang ada di PPP Tasikagung. Pengambilan sampel menggunakan Accidental sampling. Menurut Nasution (2003), Accidental sampling merupakan pengambilan sampel yang dilakukan tanpa direncanakan terlebih dahulu, sehingga jumlah sampel yang dikehendaki tidak berdasarkan pertimbangan, tetapi didasarkan atas kebutuhan yang diperlukan saja.

\section{Analisis OWAS}

Menganalisa dan mengidentifikasi postur tubuh anak buah kapal (ABK) saat melakukan kegiatan pra-penangkapan, operasi penangkapan dan pasca penangkapan. Karhu 1981 menyatakan klasifikasi dalam penentuan postur kerja dengan menggunakan metode OWAS sebagai berikut:

1) Penilaian pada punggung digunakan nilai $1-4$

$1=$ Tegak

2 = Membungkuk ke depan atau ke belakang

$3=$ Berputar dan bergerak ke samping

4 = Berputar dan bergerak atau membungkuk ke samping dan ke depan

2) Penilaian pada lengan digunakan nilai 1-3 untuk setiap komponen punggung

$1=$ Kedua tangan berada di bawah level ketinggian bahu

$2=$ Satu lengan berada di atas level ketinggian bahu

3 = Kedua lengan berada di atas level ketinggian bahu

3) Penilaian pada kaki digunakan nilai 1-7

$1=$ Duduk

$2=$ Berdiri dengan keadaan kedua kaki lurus

3 = Berdiri dengan cara beban berada pada salah satu kaki

$4=$ Berdiri dengan kedua lutut sedikit tertekuk

$5=$ Berdiri dengan satu lutut sedikit tertekuk 
$6=$ Jongkok dengan satu atau dua kaki

$7=$ Bergerak atau berpindah

Tabel 1 Penilaian OWAS

\begin{tabular}{|c|c|c|c|c|c|c|c|c|c|c|c|c|c|c|c|c|c|c|c|c|c|c|c|}
\hline \multirow{2}{*}{ 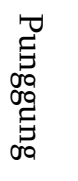 } & \multirow{2}{*}{ 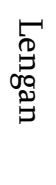 } & \multicolumn{4}{|c|}{1} & \multicolumn{3}{|c|}{2} & \multicolumn{3}{|c|}{3} & \multicolumn{2}{|l|}{4} & \multicolumn{3}{|c|}{5} & \multicolumn{3}{|c|}{6} & \multicolumn{3}{|c|}{7} & \multirow{2}{*}{$\begin{array}{c}\text { Kaki } \\
\text { Berat } \\
\text { Beban }\end{array}$} \\
\hline & & 1 & 2 & 3 & 1 & 2 & 3 & 1 & 2 & 3 & 1 & 2 & 3 & 1 & 2 & 3 & 1 & 2 & 3 & 1 & 23 & 3 & \\
\hline \multirow{4}{*}{1} & 1 & 1 & 1 & 1 & 1 & 1 & 1 & 1 & 1 & 1 & 2 & 2 & 2 & 2 & 2 & 2 & 1 & 1 & 1 & 1 & 1 & 1 & \\
\hline & 2 & 1 & 1 & 1 & 1 & 1 & 1 & 1 & 1 & 1 & 2 & 2 & 2 & 2 & 2 & 2 & 1 & 1 & 1 & 1 & 1 & 1 & \\
\hline & 3 & 1 & 1 & 1 & 1 & 1 & 1 & 1 & 1 & 1 & 2 & 2 & 2 & 2 & 2 & 2 & 1 & 1 & 1 & 1 & 1 & 1 & \\
\hline & 1 & 2 & 2 & 3 & 2 & 2 & 3 & 2 & 2 & 3 & 3 & 3 & 3 & 3 & 3 & 3 & 2 & 2 & 2 & 2 & 3 & 3 & \\
\hline \multirow[t]{3}{*}{2} & 2 & 2 & 2 & 3 & 2 & 2 & 3 & 2 & 3 & 3 & 3 & 4 & 4 & 3 & 4 & 4 & 3 & 3 & 4 & 2 & 3 & 4 & \\
\hline & 3 & 3 & 3 & 4 & 2 & 2 & 3 & 3 & 3 & 3 & 3 & 4 & 4 & 4 & 4 & 4 & 4 & 4 & 4 & 2 & 3 & 4 & Nilai \\
\hline & 1 & 1 & 1 & 1 & 1 & 1 & 1 & 1 & 1 & 2 & 3 & 3 & 3 & 4 & 4 & 4 & 1 & 1 & 1 & 1 & 1 & 1 & Indeks \\
\hline \multirow[t]{3}{*}{3} & 2 & 2 & 2 & 3 & 1 & 1 & 1 & 1 & 1 & 2 & 4 & 4 & 4 & 4 & 4 & 4 & 3 & 3 & 3 & 1 & 1 & 1 & \\
\hline & 3 & 2 & 2 & 3 & 1 & 1 & 1 & 2 & 3 & 3 & 3 & 4 & 4 & 4 & 4 & 4 & 4 & 4 & 4 & 1 & 1 & 1 & \\
\hline & 1 & 2 & 3 & 3 & 2 & 2 & 3 & 2 & 2 & 3 & 4 & 4 & 4 & 4 & 4 & 4 & 4 & 4 & 4 & 2 & 3 & 4 & \\
\hline \multirow[t]{2}{*}{4} & 2 & 3 & 3 & 4 & 2 & 3 & 4 & 3 & 3 & 4 & 4 & 4 & 4 & 4 & 4 & 4 & 4 & 4 & 4 & 2 & 3 & 4 & \\
\hline & 3 & 4 & 4 & 4 & 2 & 3 & 4 & 3 & 3 & 4 & 4 & 4 & 4 & 4 & 4 & 4 & 4 & 4 & 4 & 2 & 3 & 4 & \\
\hline
\end{tabular}

4) Penilaian pada beban digunakan nilai 1-3 untuk setiap elemen penilaian kaki

$1=$ Beban sekitar $10 \mathrm{~kg}$ atau kurang

2 = Beban sekitar 10-20 kg

3 = Beban sekitar $20 \mathrm{~kg}$ atau lebih

5) Untuk analisa atau penilaian kondisi kerja digunakan nilai 1-4 pada setiap penilaian beban

$1=$ Tidak perlu dilakukan perbaikan

2 = Perlu dilakukan perbaikan

3 = Perbaikan perlu dilakukan secepat mungkin

4 = Perbaikan perlu dilakukan sekarang juga

Nilai indeks didapatkan setelah mendapatkan kode postur tubuh disetiap klarifikasi, kemudian menarik garis tegak lurus dari kedua sumbu $\mathrm{x}$ dan y sampai bertemu disatu titik (Gambar 1).

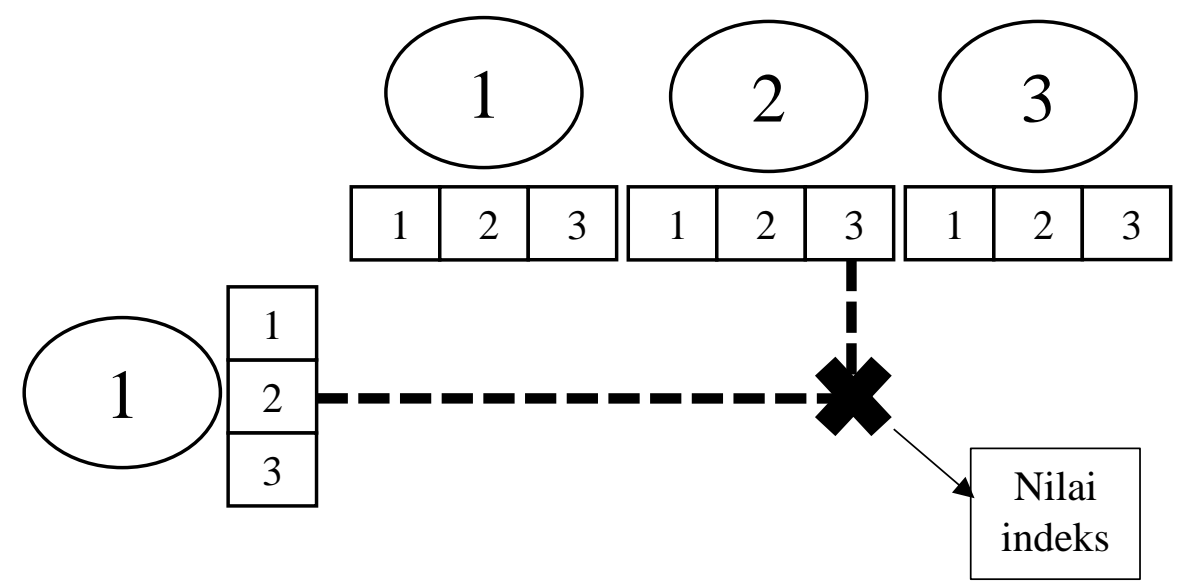

Gambar 1 Contoh menentukan nilai indeks 
Hasil dari analisa sikap kerja OWAS (Ovako Working Posture Analysis) terdiri dari empat level sikap kerja yang berbahaya bagi pekerja (Tabel 2).

Tabel 2 Kategori penilaian OWAS

\begin{tabular}{|c|c|c|c|}
\hline No & $\begin{array}{c}\text { Nilai } \\
\text { indeks }\end{array}$ & Kategori & Konsekuensi bahaya \\
\hline 1 & 1 & $\begin{array}{l}\text { Pada sikap ini tidak masalah pada sistem } \\
\text { musculoskeletal sehingga tidak perlu perbaikan }\end{array}$ & Tidak berbahaya \\
\hline 2 & 2 & $\begin{array}{l}\text { Pada sikap ini berbahaya pada sistem } \\
\text { musculoskeletal (sikap kerja mengakibatkan } \\
\text { pengaruh ketegangan yang signifikan) sehingga } \\
\text { perlu perbaikan di masa yang akan datang }\end{array}$ & Ringan \\
\hline 3 & 3 & $\begin{array}{l}\text { Pada sikap ini berbahaya bagi sistem } \\
\text { musculoskeletal (sikap kerja mengakibatkan } \\
\text { pengaruh ketegangan yang } \\
\text { signifikan) sehingga perlu perbaikan secepatnya }\end{array}$ & Menengah \\
\hline 4 & 4 & $\begin{array}{l}\text { Pada sikap ini berbahaya bagi sistem } \\
\text { musculoskeletal (sikap kerja mengakibatkan } \\
\text { pengaruh ketegangan yang signifikan) perlu } \\
\text { perbaikan secara langsung }\end{array}$ & Berat \\
\hline
\end{tabular}

2. Nordic body map

Nordic Body Map merupakan salah satu metode pengukuran subjektif untuk mengukur rasa sakit otot. Kuesioner nordic body map merupakan salah satu bentuk kuesioner cheklist ergonomi. kuesioner yang paling sering digunakan untuk mengetahui ketidaknyamanan pada pekerja karena sudah terstandarisasi dan tersusun rapi (Wilson and Corlett 1995). Kusioner nordic body map ini telah secara luas digunakan oleh para ahli ergonomi untuk menilai tingkat keparahan gangguan pada sistem musculoskeletal dan mempunyai validitas dan rehabilitas yang cukup (Tarwaka 2010). Kusioner Nordic Body Map meliputi 28 bagian otot-otot skeletal (Gambar 2). Kusioner dapat mengetahui bagian-bagian otot yang mengalami gangguan kenyerian atau keluhan (Tarwaka 2010). Keberhasilan aplikasi metode ini sangat tergantung dari kondisi dan situasi yang dialami pekerja saat dilakukannya peneltian dan juga tergantung dari keahlian dan pengalaman observer yang bersangkutan. 


$\begin{array}{lll}\text { No } & \text { Bagian tubuh } \\ 0 & \text { Leher bagian atas } \\ 1 & \text { Leher bagian bawah } \\ 2 & \text { Bahu kiri } \\ 3 & \text { Bahu kanan } \\ 4 & \text { Lengan atas kiri } \\ 5 & \text { Punggung } \\ 6 & \text { Lengan atas kanan } \\ 7 & \text { Pinggang } \\ 8 & \text { Bokong } \\ 9 & \text { Pantat } \\ 10 & \text { Siku kiri } \\ 11 & \text { Siku kanan } \\ 12 & \text { Lengan bawah kiri } \\ 13 & \text { Lengan bawah kanan } \\ 14 & \text { Pergelangan tangan kiri } \\ 15 & \text { Pergelangan tangan kanan } \\ 16 & \text { Tangan kiri } \\ 17 & \text { Tangan kanan } \\ 18 & \text { Paha kiri } \\ 19 & \text { Paha kanan } \\ 20 & \text { Lutut kiri } \\ 21 & \text { Lutut kanan } \\ 22 & \text { Betis kiri } \\ 23 & \text { Betis kanan } \\ 24 & \text { Pergelangan kaki kiri } \\ 25 & \text { Pergelangan kaki kanan } \\ 26 & \text { Kaki kiri } \\ & 27 & \text { Kaki kanan } \\ & \\ & \end{array}$

Gambar 2 Nordic Body Map

\section{HASIL DAN PEMBAHASAN}

\section{Penilaian OWAS pada aktivitas penangkapan ikan dengan menggunakan alat tangkap mini purse seine}

Penilaian diberikan pada bagian tubuh nelayan purse seine yang sedang melakukan kegiatan penangkapan ikan dari persiapan, operasi penangkapan dan aktivitas bongkar muat.

Tabel 3 Penilaian postur tubuh pada aktivitas perbekalan

\begin{tabular}{lcccccc}
\hline \multirow{2}{*}{\multicolumn{1}{c}{ Aktivitas }} & \multicolumn{5}{c}{ Posisi tubuh } & \multirow{2}{*}{ Konsekuensi bahaya } \\
\cline { 2 - 5 } & P & L & K & B & N & Berat \\
\hline Memindahkan bahan bakar ke kapal & 4 & 3 & 4 & 2 & 4 & Berat \\
Memindahkan es batu ke kapal & 4 & 3 & 4 & 2 & 4 & Menengah \\
Menerima dan memindahkan es batu & 2 & 1 & 7 & 2 & 3 & Menengah \\
Menerima es batu dari dek di palka & 4 & 3 & 3 & 2 & 3 & Menengah \\
Menyusun es batu di palka & 2 & 1 & 4 & 2 & 3 & Berat \\
Memindahkan bahan bakar ke palka & 4 & 1 & 4 & 2 & 4 & Tidak berbahaya \\
Memindahkan rumpon ke kapal & 3 & 3 & 3 & 1 & 1 & Ringan \\
Menyusun rumpon di kapal & 4 & 1 & 3 & 1 & 2 & \\
\hline
\end{tabular}

P: Punggung, L: Lengan, K: Kaki, B: Berat Beban, N: Nilai Indeks 
Seluruh aktivitas perbekalan melibatkan sikap kerja berdiri, sebagian besar dilakukan dengan posisi punggung membungkuk dan tegak memutar serta kedua lengan berada diatas dan dibawah bahu. Konsekuensi bahaya berat dan menengah didapatkan paling banyak dan kosekuensi bahaya tidak berbahaya dan ringan didapatkan paling sedikit (Tabel 3).

Aktivitas perbekalan dapat menyebakan musculoskeletal disorders karena pada setiap aktivitas perbekalan sebagian besar dilakukan dengan mengangkat beban. Aktivitas pemindahan dipengaruhi oleh ketinggian karena proses pemindahan dilakukan dari kapal pengangkut yang memiliki tinggi kapal lebih kecil dibanding kapal perikanan purse seine, maka mengakibatkan pengangkatan beban melebihi bahu. Bila bahu harus mengangkat beban yang berat dan aktivitas melibatkan pengangkatan lengan melebihi atau sebatas akroniom posisi ini bila berlangsung secara terus menerus dapat menyebabkan terjadinya iskemia pada tendon dan menyebabkan nyeri (Schwartz 2000). Selain posisi bahu yang melebihi atau sejajar akroniom jarak juga dapat menyebabkan keluhan pada otot. Terdapat perbedaan dalam menetukan beban normal yang dibawa oleh manusia. Hal ini dipengaruhi oleh frekuensi dari pekerjaan yang dilakukan.

Faktor yang paling berpengaruh dari kegiatan membawa beban adalah jarak. Jarak yang ditempuh semakin jauh akan menurunkan batasan beban yang dibawa (Bridger 1995). Hal ini menandakan aktivitas perbekalan tergolong mebahayakan untuk sistem musculoskeletal.

Tabel 4 Penilaian postur tubuh pada aktivitas setting alat tangkap

\begin{tabular}{lcccccc}
\hline \multirow{2}{*}{ Aktivitas } & \multicolumn{5}{c}{ Posisi tubuh } & \multirow{2}{*}{ Konsekuensi bahaya } \\
\cline { 2 - 6 } & $\mathrm{P}$ & $\mathrm{L}$ & $\mathrm{K}$ & $\mathrm{B}$ & $\mathrm{N}$ & \\
\hline \multirow{3}{*}{ Penurunan alat tangkap } & 2 & 1 & 4 & 3 & 3 & Menengah \\
& 2 & 1 & 2 & 3 & 3 & Menengah \\
Penarikan tali kolor & 2 & 1 & 3 & 3 & 3 & Menengah \\
& 2 & 1 & 4 & 3 & 1 & Tidak berbahaya \\
Menggulung tali kolor & 3 & 1 & 4 & 3 & 3 & Menengah \\
Mengoperasikan gardan & 3 & 1 & 2 & 3 & 3 & Menengah \\
\hline & 4 & 1 & 2 & 3 & 3 & Menengah \\
\hline
\end{tabular}

P: Punggung, L: Lengan, K: Kaki, B: Berat Beban, N: Nilai Indeks

Aktivitas setting melibatkan sikap kerja berdiri dengan posisi punggung dalam keadaan membungkuk dan memutar serta posisi kaki yang berbeda-beda setiap ABK. Konsekuensi bahaya berat tidak didapatkan pada aktivitas setting, terbanyak konskuensi bahaya menengah dan konsekuensi bahaya ringan dan tidak berbahaya didapatkan paling sedikit (Tabel 4). Penarikan tali kolor dan mengoperasikan gardan dilakukan dengan posisi tubuh dalam keadaan membungkuk dan tegak memutar yang dilakukan secara berulang-ulang dan berat beban yang besar. Kaki memiliki peran penting pada penarikan tali kolor karena kaki berfungsi sebagai tumpuan dan menjaga keseimbangan supaya saat proses penarikan, nelayan tidak terjatuh dan terseret akibat berat beban dari alat tangkap dan arus laut.

Hal ini dapat menyebabkan musculoskeletal disorders pada bagian kaki. Berat tubuh manusia akan ditopang oleh satu ataupun kedua kaki ketika melakukan posisi berdiri. Aliran beban berat tubuh mengalir pada kedua kaki menuju tanah. Kestabilan tubuh ketika posisi berdiri dipengaruhi oleh posisi kedua kaki. Kaki yang sejajar lurus dengan jarak sesuai dengan tulang pinggul akan menjaga tubuh dari tergelincir. Selain itu perlu menjaga kelurusan antara anggota tubuh bagian atas dengan anggota tubuh bagian bawah. Sikap kerja berdiri memiliki beberapa permasalahan sistem musculoskeletal. Nyeri punggung bagian bawah (low back pain) menjadi salah satu permasalahan posisi sikap kerja berdiri dengan sikap punggung condong ke depan. Posisi berdiri yang terlalu lama akan menyebabkan 
penggumpalan pembuluh darah vena, karena aliran darah berlawanan dengan gaya gravitasi. Kejadian ini bila terjadi pada pergelangan kaki dapat menyebabkan pembengkakan (Bridger 1995).

Tabel 5 Penilaian postur tubuh pada aktivitas hauling

\begin{tabular}{ccccccc}
\hline \multirow{2}{*}{ Aktivitas } & \multicolumn{5}{c}{ Posisi tubuh } & \multirow{2}{*}{ Konsekuensi bahaya } \\
\cline { 2 - 6 } & $\mathrm{P}$ & $\mathrm{L}$ & $\mathrm{K}$ & $\mathrm{B}$ & $\mathrm{N}$ & \\
\hline \multirow{3}{*}{ Penarikan badan jaring } & 3 & 1 & 2 & 3 & 1 & Tidak berbahaya \\
& 3 & 1 & 4 & 3 & 3 & Menengah \\
\multirow{3}{*}{ Mengoperasikan gardan } & 4 & 1 & 2 & 3 & 3 & Menengah \\
\multirow{3}{*}{ Penarikan pelampung } & 4 & 1 & 3 & 3 & 3 & Menengah \\
\cline { 2 - 6 } & 4 & 1 & 4 & 3 & 4 & Berat \\
& 2 & 1 & 2 & 3 & 3 & Menengah \\
\cline { 2 - 5 } & 4 & 1 & 4 & 3 & 4 & Berat \\
& 3 & 1 & 1 & 3 & 1 & Tidak berbahaya \\
\hline
\end{tabular}

P: Punggung, L: Lengan, K: Kaki, B: Berat Beban, N: Nilai Indeks

Aktivitas hauling meliputi penarikan badan jaring, mengoperasikan gardan dan penarikan pelampung (Tabel 5). Aktivitas hauling tergolong membahayakan karena proses penarikan jaring dan pelampung ke atas kapal mempengaruhi bagian kaki karena memberikan beban yang besar sebagai tumpuan agar nelayan tidak terjatuh dari kapal akibat arus laut yang kuat serta beban kerja yang diterima nelayan yang besar melebihi $20 \mathrm{~kg}$. Seluruh aktivitas hauling dilakukan dengan sikap kerja berdiri. Sikap kerja berdiri dalam waktu lama akan membuat pekerja selalu berusaha menyeimbangkan tubuhnya sehingga menyebabkan terjadinya beban kerja statis pada otot-otot punggung dan kaki, kondisi ini dapat menyebabkan mengumpulnya darah pada bagian bawah tubuh (Pangaribuan 2009).

Konsekuensi bahaya pada tidak berbahaya terdapat pada aktivitas penarikan badan jaring dan penarikan pelampung hal ini dipengaruhi oleh kondisi punggung yang dilakukan dengan posisi tegak dan memutar, lengan dibawah bahu dan posisi lutut tidak tertekuk. Konsekuensi bahaya menengah didapatkan pada aktivitas penarikan badan jaring dan pengoperasian gardan dan konsekuensi bahaya berat didapatkan pada aktivitas penarikan pelampung dikarenakan pada aktivitas ini posisi punggung dengan keadaan membungkuk dan memutar dan posisi kedua lutut tertekuk yang diakibatkan ABK butuh tenaga yang lebih besar dibanding proses penarikan jaring.

Tabel 6 Penilaian postur tubuh pada aktivitas sortir ikan

\begin{tabular}{|c|c|c|c|c|c|c|}
\hline \multirow{2}{*}{ Aktivitas } & \multicolumn{5}{|c|}{ Posisi tubuh } & \multirow{2}{*}{ Konsekuensi bahay } \\
\hline & $\mathrm{P}$ & $\mathrm{L}$ & $\mathrm{K}$ & B & $\mathrm{N}$ & \\
\hline \multirow{2}{*}{ Memilah hasil tangkapan } & 2 & 1 & 1 & 1 & 2 & Ringan \\
\hline & 4 & 1 & 1 & 1 & 2 & Ringan \\
\hline $\begin{array}{l}\text { Mengambil keranjang dan es batu } \\
\text { dari palka }\end{array}$ & 4 & 3 & 2 & 2 & 3 & Menengah \\
\hline $\begin{array}{l}\text { Menerima keranjang dan es batu } \\
\text { dari palka }\end{array}$ & 4 & 3 & 2 & 2 & 3 & Menengah \\
\hline Memecahkan es batu dengan palu & 1 & 3 & 2 & 1 & 1 & Tidak berbahaya \\
\hline Menahan es batu & 1 & 1 & 2 & 2 & 1 & Tidak berbahaya \\
\hline
\end{tabular}

P: Punggung, L: Lengan, K: Kaki, B: Berat Beban, N: Nilai Indeks

Aktivitas sortir ikan melibatkan sikap kerja berdiri dengan keadaan membungkuk dan sikap kerja duduk dengan posisi punggung membungkuk dan memutar. Sebagian ABK dengan posisi tegak dan membungkuk serta posisi tangan berada dibawah bahu. Keadaan sikap kerja anak buah kapal yang sedang mengambil keranjang dari palka dengan poisisi tubuh membungkuk dengan tangan dibawah 
bahu kemudian berputar tegak dengan poisi tangan diatas bahu untuk mengoper keranjang ke atas dek kapal. Posisi tubuh ABK saat memecahkan es batu, 1 ABK menahan es batu dengan keadaan posisi tubuh tegak dengan posisi kaki lurus dan tahan di bawah bahu sedangkan 1 ABK yang sedang memegang palu pemukul es dengan posisi tubuh tegak dengan posisi lutut tertekuk dan poisisi lengan diatas bahu kemudian palu digerakan posisi tubuh berubah menjadi posisi badan tegak dengan keadaan lutut tertekuk dan posisi lengan dibawah bahu.

Penilaian postur OWAS pada aktivitas memilah ikan konsekuensi bahaya tidak berbahaya, ringan dan menengah (Tabel 6). Kegiatan menahan es batu dan memecahkan es batu mendapatkan konsekuensi bahaya tidak berbahaya sehingga tidak menimbulkan dampak yang signifikan terhadap sistem musculoskeletal pada tubuh manusia. Sedangkan kegiatan mengambil dan menerima keranjang ikan dan es batu dari dalam palka dan dek kapal mendapatkan konsekuensi bahaya menengah berdasarkan kegitan yang mebebankan posisi punggung dan lengan yang diakibatkan oleh besarnya beban dan kondisi lingkungan yang sempit sehingga sulit untuk melakukan posisi yang sesuai.

Salah satu sikap kerja yang tidak nyaman untuk diterapkan dalam pekerjaan adalah membungkuk. Posisi ini tidak menjaga kestabilan tubuh ketika bekerja. Pekerja mengalami keluhan rasa nyeri pada bagian punggung bagian bawah (low back pain) bila dikukan secara berulang dan periode yang cukup lama (Bridger 1995).

Tabel 7 Penilaian postur tubuh pada aktivitas perbaikan jaring

\begin{tabular}{llllllll}
\hline \multirow{2}{*}{ Aktivitas } & \multicolumn{4}{c}{ Posisi tubuh } & \multirow{2}{*}{ Konsekuensi bahaya } \\
\cline { 2 - 5 } & $\mathrm{P}$ & $\mathrm{L}$ & $\mathrm{K}$ & $\mathrm{B}$ & $\mathrm{N}$ & \\
\hline Menambal jaring & 2 & 1 & 1 & 1 & 2 & Ringan \\
\hline P: Punggung, L: Lengan, K: Kaki, B: Berat Beban, N: Nilai Indeks & &
\end{tabular}

Aktivitas menambal jaring melibatkan sikap kerja duduk dengan posisi punggung membungkuk dan poisi lengan dibawah bahu. Posisi ini menimbulkan rasa sakit pinggang dan sakit punggung karena dilakukan dalam waktu berkisar 5-6 jam. Konsekuesi bahaya yang didapatkan adalah ringan sehingga tidak terlalu membebani sistem musculoskeletal pada tubuh manusia (Tabel 7). Aktivitas perbaikan jaring dilakukan dengan postur statis. Postur statis adalah postur yang terjadi dimana sebagian besar tubuh tidak aktif atau hanya sedikit sekali terjadi pergerakan. Postur statis dalam jangka waktu lama dengan kontraksi otot secara terus-menerus dapat menyebabkan tekanan atau stress pada bagian tubuh (Bridger 2003).

Sikap kerja duduk menyebabkan otot bagian paha semakin tertarik dan bertentangan dengan bagian pinggul. Akibatnya tulang pelvis akan miring ke belakang dan tulang belakang bagian lumbar akan mengendor. Mengendor pada bagian lumbar menjadikan sisi depan invertebratal disk tertekan dan sekelilingnya melebar atau merenggang bagian bawah dan menyebar pada kaki. Ketegangan saat melakukan sikap kerja duduk seharusnya dapat dihindari dengan melakukan perancangan tempat duduk. Posisi duduk tanpa memakai sandaran akan menaikan tekanan pada invertebaratal disk sebanyak 1/3 hingga 1/2 lebih banyak daripada posisi berdiri (Kroemer 2001). Sikap kerja duduk pada kursi memerlukan sandaran punggung untuk menopang punggung. Sandaran yang baik adalah sandaran punggung yang bergerak maju-mundur untuk melindungi bagian lumbar. Sandaran tersebut juga memiliki tonjolan ke depan untuk menjaga ruang lumbar yang sedikit menekuk. Hal ini dimaksudkan untuk mengurangi tekanan pada bagian invertebratal disk (Bridger 1995).

Aktivitas pemasangan rumpon melibatkan sikap kerja berdiri dengan posisi punggung membungkuk dan banyak melibatkan posisi kaki dalam keadaan lutut tertekuk. Posisi punggung dalam keadaan mebungkuk. Salah satu sikap kerja yang tidak nyaman untuk diterapkan dalam pekerjaan adalah membungkuk. Posisi ini tidak menjaga kestabilan tubuh ketika bekerja. Pekerja mengalami keluhan rasa nyeri pada bagian punggung bagian bawah (low back pain) bila dikukan secara berulang 
dan periode yang cukup lama. Pada saat membungkuk tulang punggung bergerak ke sisi depan tubuh. Otot bagian perut dan sisi depan invertebratal disk pada bagian lumbar mengalami penekanan.

Tabel 8 Penilaian postur tubuh pada aktivitas pemasangan rumpon

\begin{tabular}{lcccccc}
\hline \multirow{2}{*}{\multicolumn{1}{c}{ Aktivitas }} & \multicolumn{5}{c}{ Posisi tubuh } & \multirow{2}{*}{ Konsekuensi bahaya } \\
\cline { 2 - 6 } & $\mathrm{P}$ & $\mathrm{L}$ & $\mathrm{K}$ & $\mathrm{B}$ & $\mathrm{N}$ & \\
\hline Menarik rumpon & 4 & 1 & 4 & 3 & 4 & Berat \\
Mengoperasikan gardan & 2 & 1 & 2 & 3 & 3 & Menengah \\
Menyusun rumpon & 2 & 1 & 1 & 1 & 2 & Ringan \\
Mengikat rumpon pada pemberat & 2 & 1 & 4 & 1 & 3 & Menengah \\
Melempar pelampung tanda & 2 & 1 & 4 & 1 & 3 & Menengah \\
& 4 & 1 & 4 & 2 & 3 & Menengah \\
\hline
\end{tabular}

P: Punggung, L: Lengan, K: Kaki, B: Berat Beban, N: Nilai Indeks

Pada bagian ligament sisi belakang dari invertebratal disk justru mengalami peregangan atau pelenturan. Sikap kerja membungkuk dapat menyebabkan "slipped disks", bila dibarengi dengan pengangkatan beban berlebih. Prosesnya sama dengan sikap kerja membungkuk, tetapi akibat tekanan yang berlebih menyebabkan ligament pada sisi belakang lumbar rusak dan penekanan pembuluh syaraf. Kerusakan ini disebabkan oleh keluarnya material pada invertebratal disk akibat desakan tulang belakang bagian lumbar (Bridger 1995). Konsekuensi bahaya paling banyak didapatkan pada konsekuensi bahaya menengah dan paling sedikit pada konsekuensi bahaya ringan (Tabel 8).

Tabel 9 Penilaian postur tubuh pada aktivitas bongkar muat

\begin{tabular}{llllllll}
\hline \multirow{2}{*}{ Aktivitas } & \multicolumn{9}{c}{ Posisi tubuh } & \multirow{2}{*}{ Konsekuensi bahaya } \\
\cline { 2 - 5 } & $\mathrm{P}$ & $\mathrm{L}$ & $\mathrm{K}$ & $\mathrm{B}$ & $\mathrm{N}$ & \\
\hline Memindahkan hasil tangkapan ke atas dek & 4 & 3 & 2 & 3 & 4 & Berat \\
Menerima hasil tangkapan dari palka & 4 & 1 & 4 & 3 & 4 & Berat \\
Memindahkan hasil tangkapan ke daratan & 4 & 3 & 3 & 3 & 4 & Berat \\
\hline
\end{tabular}

P: Punggung, L: Lengan, K: Kaki, B: Berat Beban, N: Nilai Indeks

Aktivitas bongkar muat tergolong aktivitas yang membahayakan bagi nelayan dikarenakan aktivitasnya melibatkan sikap kerja berdiri dengan posisi punggung saat melakukan kegiatan dengan keadaan membungkuk dan memutar dan kondisi lengan yang berada diatas bahu saat mengangkat beban yang beratnya melebihi $20 \mathrm{~kg}$ serta kondisi kaki yang menahan beban. Aktivitas bongkar muat dilakukan tidak berdasarkan kondisi pasang dan surut air laut sehingga kondisi surut mempengaruhi jarak ketinggian antara kapal dan daratan, hal ini dapat mempengaruhi pengangkatan beban melebihi bahu, sehingga seluruh aktvitasnnya mendapatkan konsekuensi bahaya berat (Tabel 9).

Terdapat perbedaan dalam menetukan beban normal yang dibawa oleh manusia. Hal ini dipengaruhi oleh frekuensi dari pekerjaan yang dilakukan. Faktor yang paling berpengaruh dari kegiatan membawa beban adalah jarak. Jarak yang ditempuh semakin jauh akan menurunkan batasan beban yang dibawa (Bridger 1995). Beban yang berlebihan mengakibatkan perenggangan otot yang terlalu berlebih yang melebihi kemampuan optimum otot yang dapat meningkatkan risiko keluhan otot (Vi 2000).

Konsekuensi bahaya pada aktivitas pra-operasi penangkapan, operasi penangkapan dan pascaoperasi penangkapan yang diperoleh dari penilaian OWAS berdasarkan nilai indeks yang didapatkan sebanyak nilai. Presentase terbanyak terdapat pada konsekuensi bahaya menengah dengan presentase $45 \%$ dan terendah pada konsekuensi bahaya ringan dengan presentase $14 \%$. 


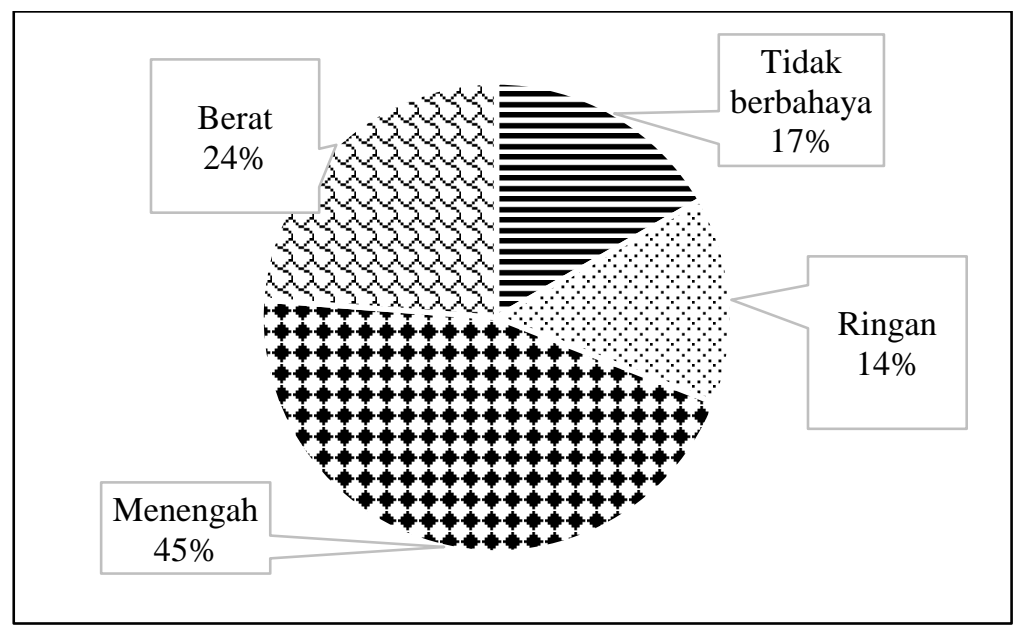

Gambar 3 Presentase konsekuensi bahaya aktivitas penankapan ikan

\section{Nordic body map}

Identifikasi keluhan otot nelayan purse seine terhadap postur keja saat melakukan kegiatan operasi penangkapan ikan diperoleh dari wawancara sebanyak 100 responden nelayan purse seine di Kabupaten Rembang yang ditampilkan dalam bentuk diagram dan dibagi menjadi 3 diagram yaitu, diagram keluhan otot pada tubuh bagian atas, diagram keluhan otot pada tubuh bagian tengah dan diagram keluhan otot pada tubuh bagian bawah.

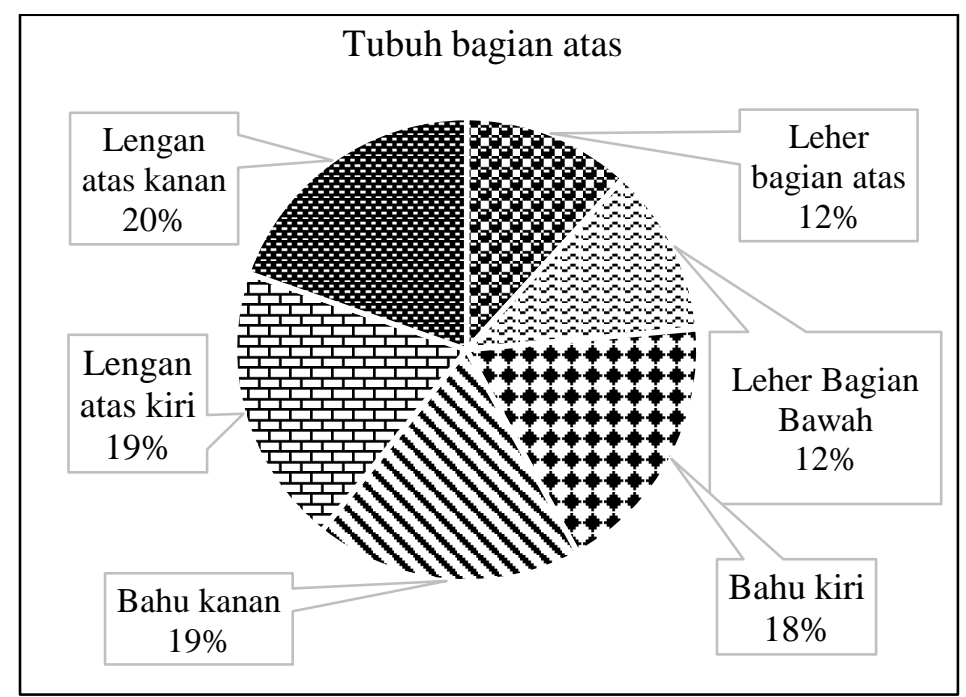

Gambar 4 Presentase keluhan otot pada tubuh bagian atas

Responden yang merasakan keluhan otot pada tubuh bagian lengan atas kiri dan lengan atas kanan sebanyak 85 responden dengan presentase $20 \%$. Sebanyak 51 responden dengan presentase 12 $\%$ merasakan keluhan otot pada leher bagian atas dan leher bagian bawah dan sebanyak 80 responden dengan presentase $18 \%$ merasakan keluhan otot pada bagian bahu kiri sedangkan pada bagian bahu kanan sebanyak 81 responden dengan presentase 19\% merasakan keluhan otot (Gambar 4).

Keluhan otot yang dirasakan pada bagian bahu dan lengan dapat terjadi bila bahu harus mengangkat beban yang berat dan aktivitas yang melibatkan pengangkatan lengan atau segaris dengan bahu. Posisi tersebut bila berlangsung secara terus-menerus akan menyebabkan terjadinya iskemia pada tendon yang menyebabkan nyeri (Scwartz 2000). Leher merupakan bagian tubuh yang perlindungannya lebih sedikit dibandingkan batang tubuh yang lain sehingga leher rentan terkenan trauma atau kelaian yang menyebabkan nyeri pada leher dan gangguan gerakan terutama bila dilakukan gerakan yang mendadak dan bekerja pada postur yang tidak sesuai (Muttaqin 2008). 
Aktivitas penangkapan ikan melibatkan penggunaan bahu dan lengan secara intensitas yang tinggi sehingga terjadinya keluhan otot pada bagian tersebut tidak dapat terhindarkan.

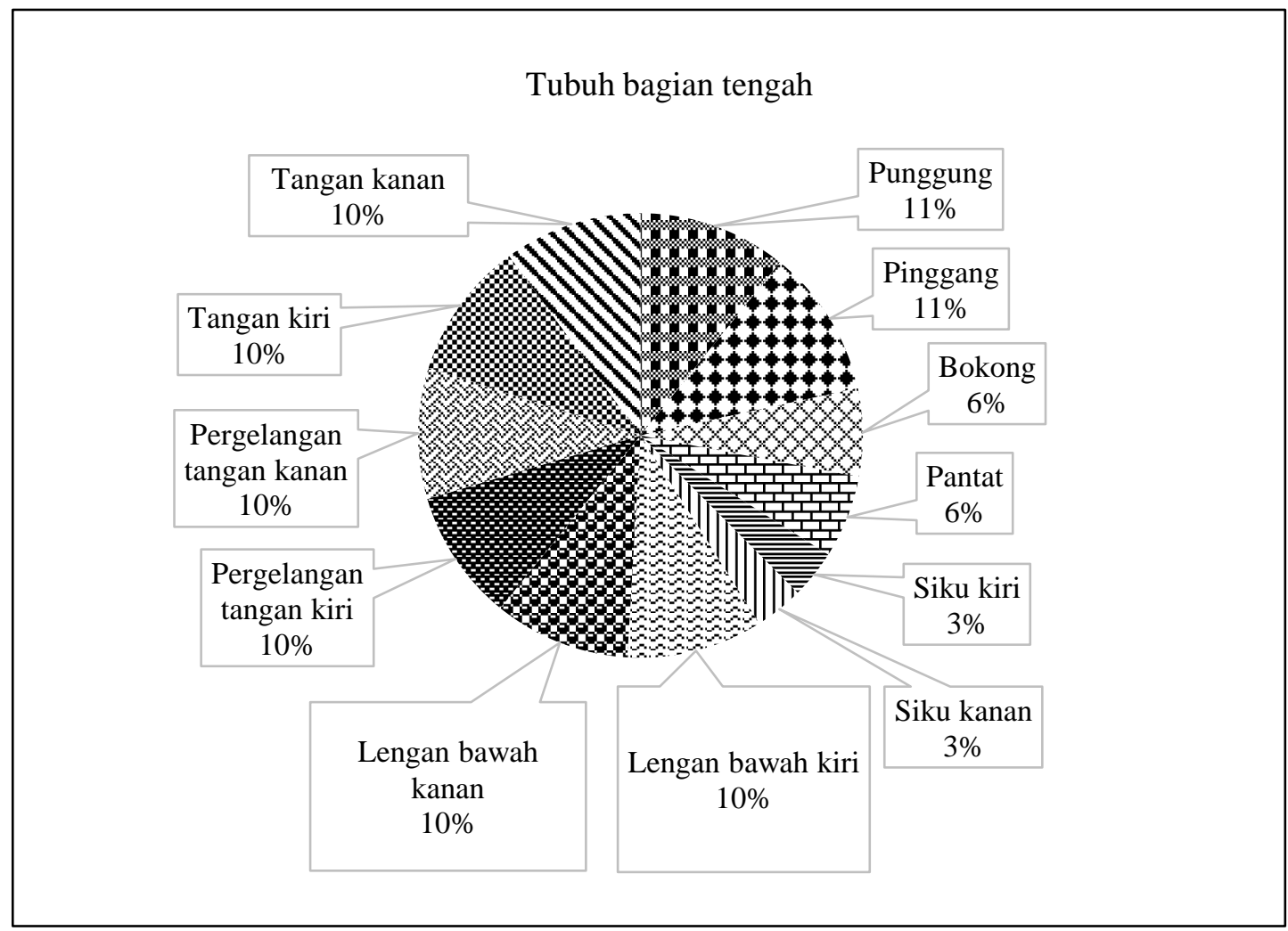

Gambar 5 Presentase keluhan otot pada tubuh bagian tengah

Responden yang merasakan rasa keluhan otot pada tubuh bagian punggung dan pinggang sebanyak 86 responden dengan presentase 11\%. sebanyak 80 responden dengan presentase 10\% merasakan keluhan otot dibagian tangan kiri dan tangan kanan. Sebanyak 79 responden dengan presentase $10 \%$ merasakan keluhan otot dibagian lengan bawah kiri dan lengan bawah kanan. Sebanyak 76 responden dengan presentase 10\% merasakan keluhan otot dibagian pergelangan tangan kanan dan pergelangan tangan kiri. Sebanyak 51 responden dengan presentase 6\% merasakan keluhan otot dibagian bokong. Sebanyak 48 responden dengan presentase 6\% merasakan keluhan otot dibagian pantan dan sebanyak 28 responden dengan presentase 3\% merasakan keluhan dibagian siku kiri dan siku kanan. Keluhan yang dirasakan paling banyak pada bagian tubuh punggung dan pinggang sebanyak 86 dengan presentase 10\%. Sedangkan keluhan otot yang dirasakan paling sedikit pada bagian siku kiri dan siku kanan hanya sebanyak 23 responden dengan presentase 3\% (Gambar 5).

Aktivitas pengkapan ikan hampir semunya dilakukan dengan posisi punggung membungkuk. Lukman (2012) menyatakan bahwa postur yang tidak alamiah sepeti punggung yang terlalu membungkuk mengakibatkan posisi tubuh semakin menjauh dari pusat gravitasi tubuh, maka semakin tinggi pula risiko terjadinya keluhan otot skeletal atau sering disebut musculoskeletal disorders. Sikap kerja yang atau posisi kerja yang tidak alamiah dapat mengakibatkan munculnya keluhan penyakit berupa WMDs (work related musculoskeletal disoeders) (Jalajuwita 2015).

Keluhan siku terjadi karena adanya gerakan yang terjadi pada sendi engsel humerus dan ulna. Sendi peluru antara Capitulum humeri dan radius serta kisar antara ulna dan radius dengan dipengaruhi gerakan berulang pada tangan, bebean kerja dan sikap tubuh (Widjaja 1998). Gerakan berulang pada tangan berdampak pada lengan bawah dan pergelangan tangan yang dipengaruhi oleh aktivitas pengangkatan beban yang berlebih. 


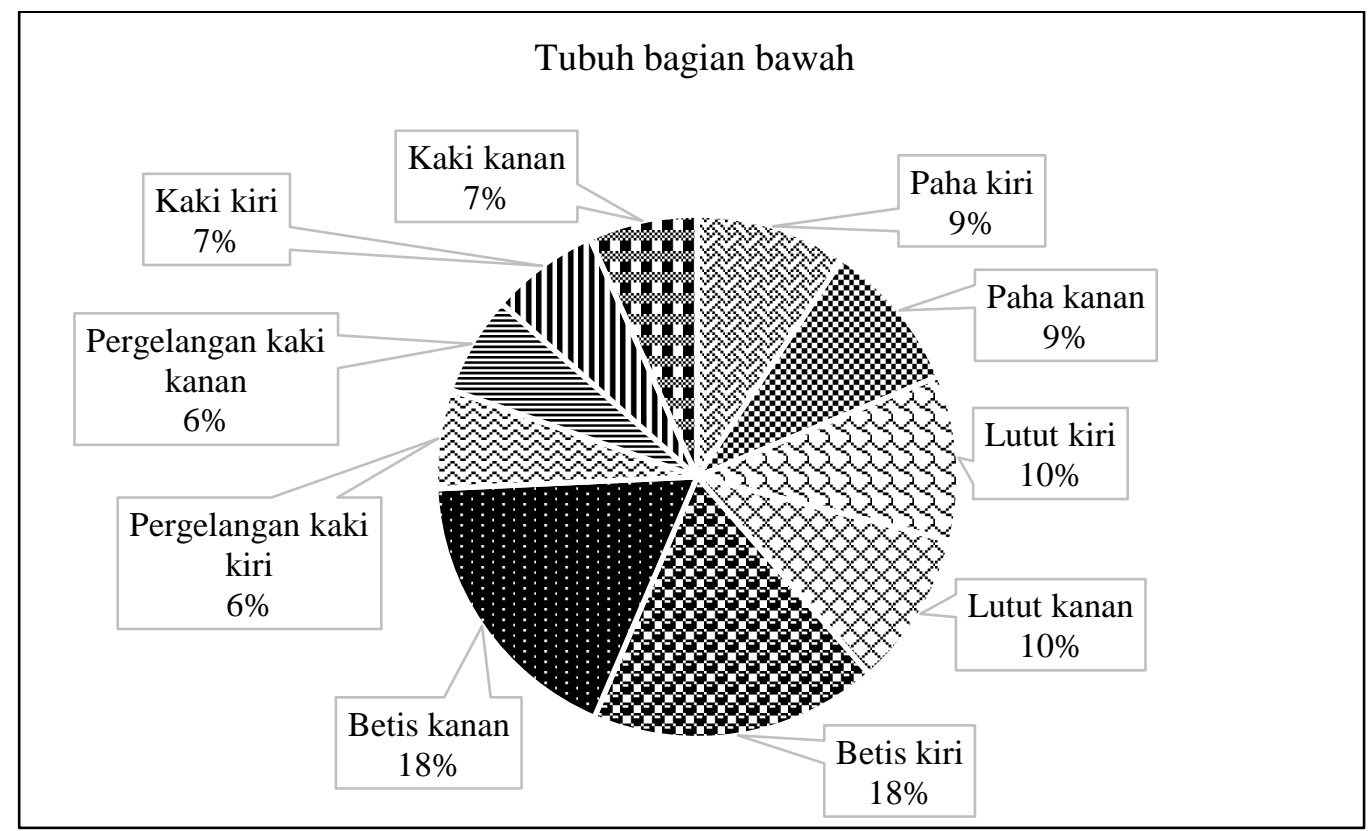

Gambar 6 Presentase keluhan otot pada tubuh bagian bawah

Responden yang merasakan keluhan otot pada tubuh bagian bawah diantaranya sebanyak keluhan yang paling banyak dirasakan dibagian betis kiri dan betis kanan sebanyak 61 responden dengan presentase $18 \%$. Sedangkan paha kanan dan paha kiri keluhan otot yang dirasakan sebanyak 21 responden dengan presentase 6\%. keluhan otot yang dirasakan dibagian lutut kanan sebanyak 33 responden dengan presentase 10\% sedangkan dibagian lutut kiri sebanyak 35 responden dengan presentase $10 \%$. sebanyak 32 responden dengan presentase $9 \%$ merasakan keluhan otot dibagian paha kiri dan paha kanan dan sebanyak 23 responden dengan presentase 7\% merasakan keluhan otot dibagian pergelangan kaki kiri dan pergelangan kaki kanan (Gambar 6).

Keluhan otot pada bagian kaki banyak dipengaruhi oleh berbagai hal diantarannya adalah postur yang tidak alamiah salah satunya kaki tidak tertopang secara sempurna dan sendi yang membentuk sudut tertentu (Rao 2012). Aktivitas penangkapan ikan cenderung dilakukan dengan posisi kaki yang sulit untuk bertumpu pada kapal, ini dikarenakan kondisi kapal yang bergerak-gerak. Keluhan pada kaki juga dipengaruhi oleh aktivitas yang dilakukan dengan lama waktu dalam keadaan berdiri. posisi berdiri dalam waktu yang cukup lama dapat mempengaruhi betis dan terjadinya pengumpalan pembuluh darah dibagian pergelangan kaki yang dapat menyebabkan pembengkakan (Bridger 1995).

\section{KESIMPULAN DAN SARAN}

\section{Kesimpulan}

1. Kondisi postur kerja nelayan purse seine saat melakukan aktivitas penangkapan ikan dilakukan dengan sikap kerja berdiri dan sikap kerja duduk. Aktivitas yang melibatkan sikap kerja berdiri yaitu perbekalan, setting, hauling, pemasangan rumpon dan bongkar muat serta yang melibatkan sikap kerja duduk yaitu sortir ikan dan perbaikan jaring.

2. Aktivitas yang tergolong membahayakan adalah aktivitas yang dilakukan dengan mengangkat beban seperti perbekalan, hauling, pemasangan rumpon dan bongkar muat. Kondisi kritis saat mengangkat beban adalah adanya perbedaan ketinggian ketika lengan mengangkat beban melebihi bahu seperti aktivitas perbekalan dan bongkar muat. 
3. Bagian tubuh yang paling banyak merasakan keluhan otot pada tubuh bagian atas adalah lengan atas kanan dan kiri sebanyak 85 responden, tubuh bagian tengah adalah punggung sebanyak 86 responden dan tubuh bagian bawah adalah betis kiri dan kanan sebanyak 61 responden dari 100 responden.

\section{Saran}

Nelayan perlu memperhatikan dan memperbaiki postur tubuh saat melakukan aktivitasaktivitas yang tergolong membahayakan pada sistem musculoskeletal dan mengurangi pengaruh tubuh yang diakibatkan saat melakukan aktivitas seperti menambah tenaga dan melakukan perenggangan disela-sela aktivitas dan memperhatikan kondisi pasang dan surut saat melakukan aktivitas perbekalan dan bongkar muat.

Peneliti perlu melakukan penelitian lanjutan terkait kondisi lingkungan kapal seperti luas dek kapal, luas palka, pengaruh area kerja untuk melihat dampak yang terjadi akibat kondisi area kerja dan pengaruh umur, kebiasaan merokok, kesehatan gizi dan lama bekerja nelayan serta Pemerintah perlu mengadakan penyuluhan terkait gangguan-gangguan otot yang diakibatkan oleh aktivitas penangkapan ikan dan memberitahukan risiko yang terjadi.

\section{DAFTAR PUSTAKA}

Bridger RS. 1995. Introduction to The Ergonomic. New York (US): International Edition.

Budiono. 2003. Bunga Rampai Hiperkes dan Keselamatan Kerja. Semarang (ID): UNDIP

Grainger CR. 1993. Hazards of Commercial Fishing. World Health Forum. 14(1): 313-315. WHO: Geneva. P

Harcombe H. 2014. Musculoskeletal disorders Among Nurses Compared with Two Other Occupational Groups. Occup Me. 64(8):601-607.

Jalajuwita, Rovanaya N. 2015. Hubungan Posisi Kerja Dengan Keluhan Muskuloskeletal Pada Unit Pengelasan PT. X Bekas. The Indonesian Journal of Occupational Safety and Health. 4(1): 3342.

Karhu O. 1981. Observing Working Posture in Industry: New York (US): Chapment \& Hall.

Kroemer K, et al. 2001. Ergonomics: How to Design for Ease and Efficiency 2nd ed. New Jersey (US): Prentice Half of International

Lukman, Nurma N. 2012. Asuhan Keperawatan pada Klien dengan Gangguan Sistem Musculoskeletal. Jakarta (ID): Salemba Medika.

Muttaqin, Arief. 2008. Asuhan Keperawatan Klien Gangguan Sistem Musculoskeletal . Jakarta (ID): Salemba Medika

Nasution. 2003. Metode Research (Penelitian Ilmiah). Jakarta (ID): PT Bumi Aksara.

Pangaribuan, D. M. 2009. Analisa Postur Kerja dengan Metode RULA pada Pegawai Bagian Pelayanan Perpustakaan USU Medan [Skripsi]. Universitas Sumatra Utara.

Peraturan Mentri Kelautan dan Perikanan Republik Indonesia Nomor PER.71/MEN/2016 Tentang Jalur Penangkapan Ikan dan Penempatan Alat Penangkapan Ikan di Wilayah Pengelolaan Perikanan Negara Republik Indonesia.

Rhamadani, D. 2004. Keragaan Dimensi dan Koefisien Bentuk Badan Kapal Ikan Di Beberapa Daerah Di Indonesia [Skripsi]. Bogor(ID): Institut Pertanian Bogor. 
Rao, et al. 2012. Musculoskeletal Conditions of the Foot and Ankle: Assessments and Treatment Options. NCBI

Schwartz, Seymour I. 2000. Intisari Prinsip-Prinsip Ilmu Bedah. Jakarta (ID): EGC edisi 6.

Tarwaka. 2010. Ergonomi Industri Dasar-dasar Pengetahuan Ergonomi dan Aplikasi di Tempat Kerja. Surakarta (ID): Harapan Press.

Tarwaka. 2013. Dasar-Dasar Pengetahuan Ergonomi dan Aplikasi di Tempat Kerja. Surakarta (ID): Harapan Press.

Undang Undang Republik Indonesia Nomor 45 Tahun 2009 Tentang Perikanan.

Van L. 2016. Prevalence of Musculoskeletal Symptoms Among Garment workers in Kandal province. Cambodia (KH): J Occup Health. 58: 107-117.

Vi P. 2000. Construction Health: Musculoskeletal Disorder What Are The Causes and Controls in Construction.

Widjaja. 1998. Kinesiologi; The Anatomy of Motion = Anatomi Alat Gerak. Jakarta (ID) : Fakultas kedokteran universitas indonesia

Wijaya. 2008. Analisa Postur Kerja dan Perancangan Alat Bantu Untuk Aktivitas Manual Material Handling. [Thesis]. Universitas Muhamadiyah Surakarta.

Wilson, Corlett E.N. 1995. Evaluation of Human Work, 2nd Edition. CRC Press

\section{LAMPIRAN}

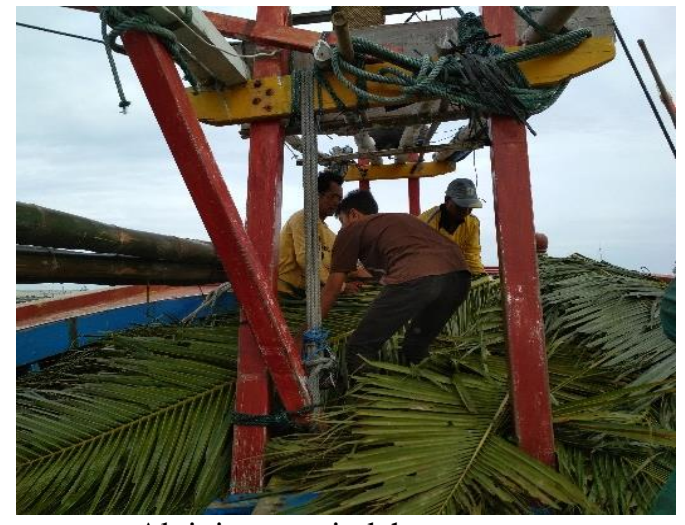

Aktivitas pemindahan rumpon

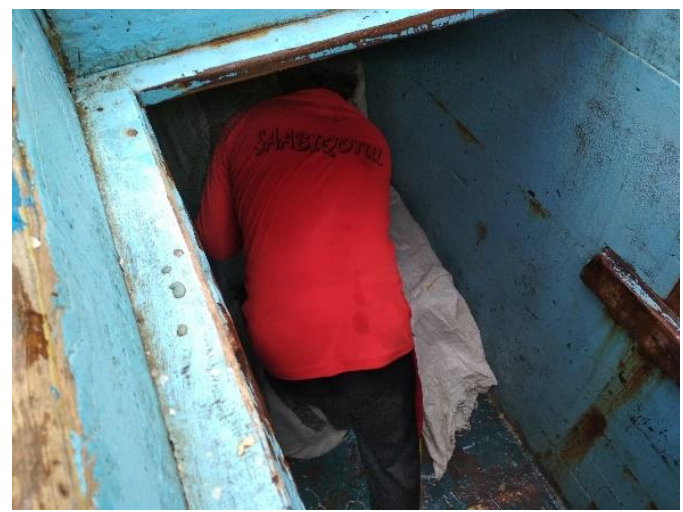

Aktivitas pemindahan es batu

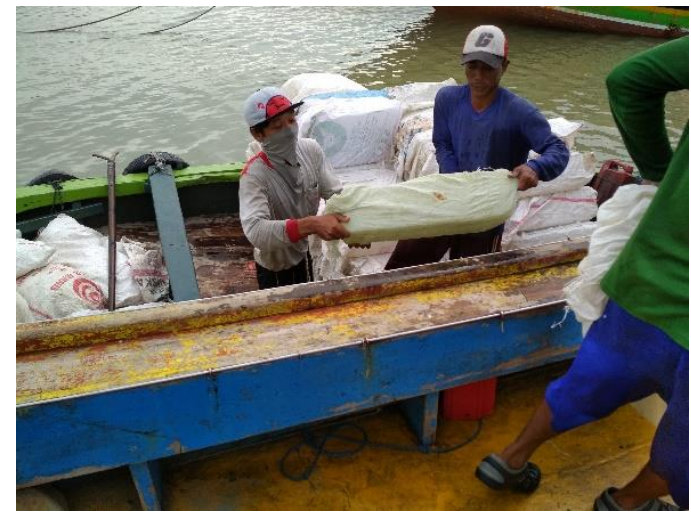

Aktivitas pemindahan es batu

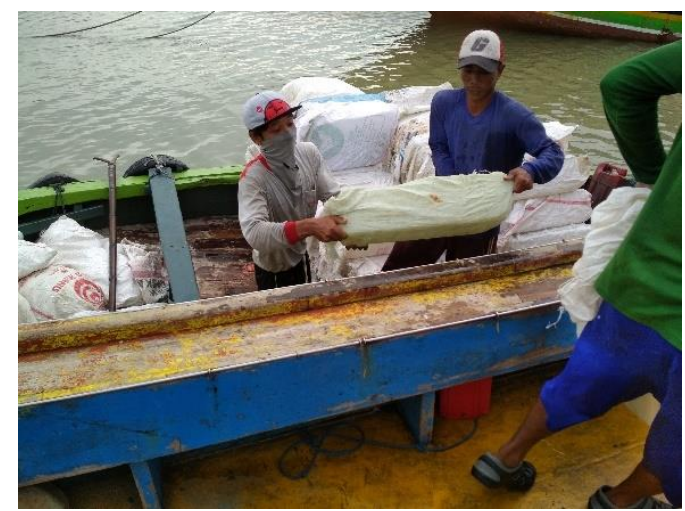

Aktivitas penyusunan es batu 


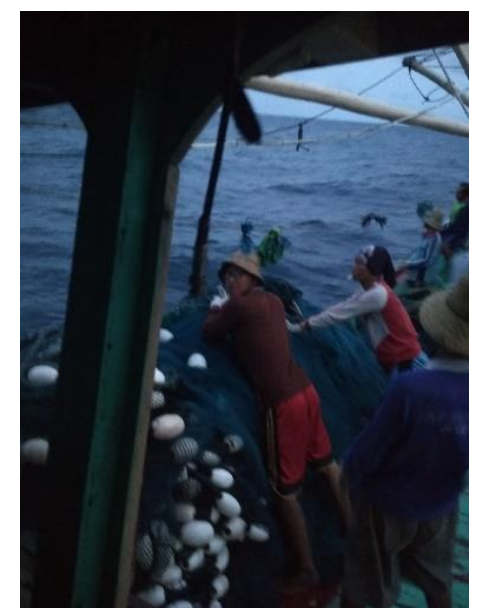

Aktivitas pelemparan alat

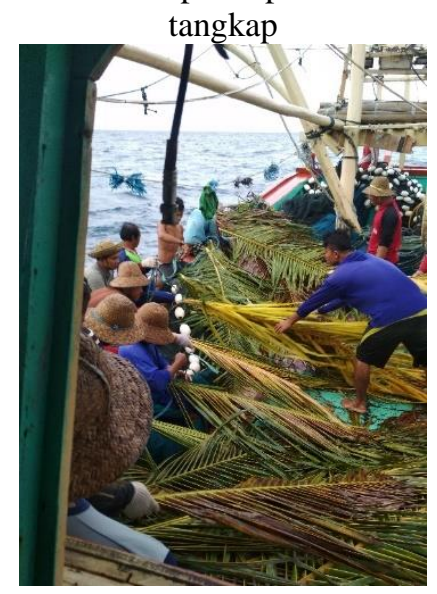

Aktivitas penyusunan rumpon

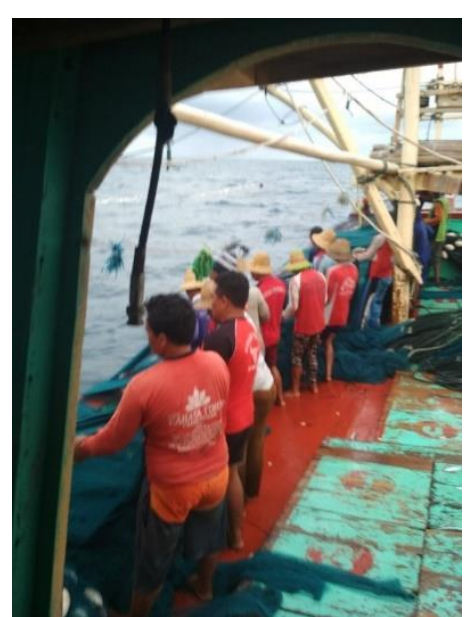

Aktivitas penarikan alat tangkap

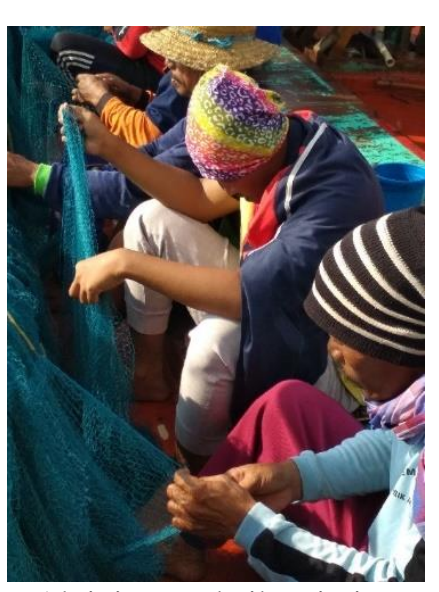

Aktivitas perbaikan jaring

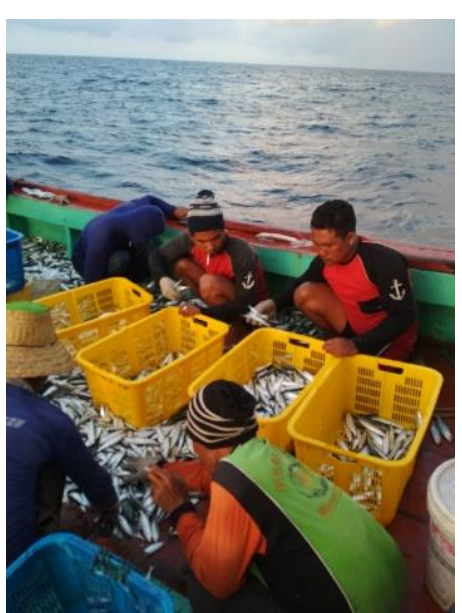

Aktivitas memilah hasil tangkapan
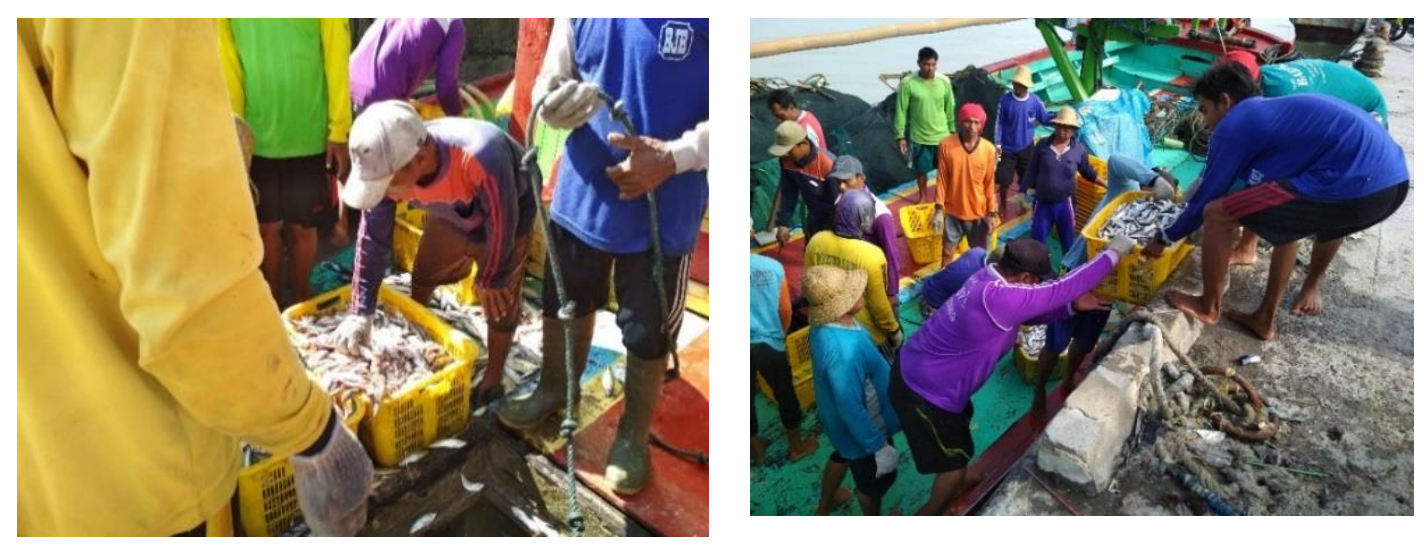

Aktivitas pemindahan hasil tangkapan ke dermaga 